\title{
Identification of carbon-based black pigments in four South American polychrome wooden sculptures by Raman microscopy
}

\author{
Eugenia P Tomasini 1,5 Blanca Gómez ${ }^{1}$, Emilia B Halac ${ }^{2,3}$, María Reinoso 2,3,5 Emiliano J Di Liscia², \\ Gabriela Siracusano $0^{4,5}$ and Marta S Maier ${ }^{1,5^{*}}$
}

\begin{abstract}
Introduction: Carbon-based pigments are a group of dark-colored materials, which are classified according to the starting material used and their manufacturing process. Raman spectroscopy is an ideal technique for the identification of carbonaceous matter. Carbon-based pigments show broad bands between 1,300 and 1,600 $\mathrm{cm}^{-1}$ but they differ in position, width and relative intensity, allowing discrimination between them. The aim of the present study was the identification of carbon-based pigments in four polychrome wooden sculptures from the Jesuit Mission La Trinidad in Paraguay.

Results: Analysis of the Raman spectral parameters of the polychrome samples and comparison with those of carbon-based pigment references allowed the identification of wood charcoal, lampblack, bistre and a black earth pigment. Complementary analysis by infrared spectroscopy and elemental analysis supported the assignments.

Conclusions: In this study we have provided new evidence that Raman microscopy is a powerful technique for the discrimination of carbon-based pigments in works of art. This is the first time that bistre, lampblack and a black earth pigment are identified in colonial art. The chemical information obtained on the black pigments contributed to increase our knowledge on available resources and technology used in the manufacture of the polychrome sculptures at the Jesuit Mission. This information is relevant for our studies on Colonial art.
\end{abstract}

Keywords: Carbon-based pigments, Raman microscopy, Polychrome sculpture, Colonial art, SEM-EDS, FT-IR

\section{Background}

Carbon-based pigments are a group of dark-colored materials that are classified according to the starting material and the manufacturing process. They are composed by some form of elemental carbon and four groups may be distinguished: graphite, flame carbons, chars, and cokes [1-3]. On the other hand, black earths containing amorphous carbonaceous materials, such as Vandyke brown and Cassel earth have also been used as pigments. These humic-earth materials are composed of complex mixtures of natural organic substances derived from

\footnotetext{
*Correspondence: maier@qo.fcen.uba.ar

1 UMYMFOR-CONICET and Departamento de Química Orgánica, Facultad de Ciencias Exactas y Naturales, Universidad de Buenos Aires, Pabellón 2, Ciudad Universitaria, C1428EGA Ciudad Autónoma de Buenos Aires, Argentina

Full list of author information is available at the end of the article
}

animal and vegetable sources with varying proportions of mineral matter [4].

Carbon-based pigments have been identified in archaeological artifacts [5], rock art [6], and in easel and wall paintings $[1,3,4,7]$. In most cases, the pigment was assumed to be charcoal or simply "carbon black", a term generally used to mean any pigment based on carbon [8]. As the precise identification of pigments is important for understanding the technology employed in the manufacture of an artwork as well as the resources available, an unambiguous characterization of carbon-based pigments remains a big challenge.

Raman spectroscopy is an ideal non-destructive technique for the characterization of a variety of carbonaceous materials because it is sensitive to crystalline and amorphous structures, allowing the study of highly disordered materials, such as carbon-based pigments $[9,10]$. 
The Raman spectrum of crystalline graphite consists of a narrow band at $1,580 \mathrm{~cm}^{-1}$ known as G band ('graphite') while disordered or microcrystalline graphite presents an additional band around $1,350 \mathrm{~cm}^{-1}$ known as D band, often called the 'disorder' band. Raman spectra of amorphous carbons are characterized by broad bands around 1,550 and $1,350 \mathrm{~cm}^{-1}$ and several spectral parameters of these bands such as their positions, relative intensities, and band widths provide structural information and have helped to discriminate between samples from different origins [9-11]. Recently, we have studied by Raman microscopy seven carbon-based pigments used in art and as references for archaeometric studies, together with a sample of commercial vegetable charcoal, in order to find relevant parameters to distinguish between the pigments [12]. These references had been selected from ten carbon-based pigments previously studied in detail by a combination of FTIR-ATR, SEM-EDS microscopy and $\mathrm{XRD}$ to determine their structures and compositions [13]. The selected pigments comprised graphite (crystalline carbon), lampblack and bistre (flame carbons), bitumen and ivory black (cokes), commercial wood charcoal (char), and Vandyke brown and Cassel earth (black earths). Reference carbon-based pigments from different sources showed similar Raman spectra with characteristic $G$ and D bands in the range $1,350-1,600 \mathrm{~cm}^{-1}$ that differed clearly in position, width and relative intensity. The combined analysis of the spectral parameters showed that Raman microscopy allowed the discrimination of most of the reference pigments as well as the identification of carbon-based black pigments in two South American colonial paintings dated from the early 18th century [13].

The aim of the present study was to extend this approach to the identification of carbon-based black pigments in four wooden polychrome sculptures (Figures 1, $2,3,4)$ produced during the so-called Colonial period (17th-18th centuries) in the Jesuit Mission of Trinidad in Paraguay. The sculptures are currently housed at the Museum of Natural Sciences, in La Plata, Buenos Aires province, Argentina and were brought to the Museum by the naturalist Adolfo de Burgoing during the last decades of the 19th century, after his trip to the Guaraní Jesuit ruins of Trinidad Mission (Paraguay), together with visits to San Ignacio Miní, Mártires, Santa María Mayor, Concepción del Bermejo, Loreto and Apóstoles Missions (Argentina).

Images installed in churches, convents or small chapels were part of what has been identified as the process of evangelization done under the Spanish domain. Virgins, saints, and christs were manufactured in workshops by Spanish, indigenous and creoles people, who used diverse materials-wood, stone, etc.-to carve and paint the

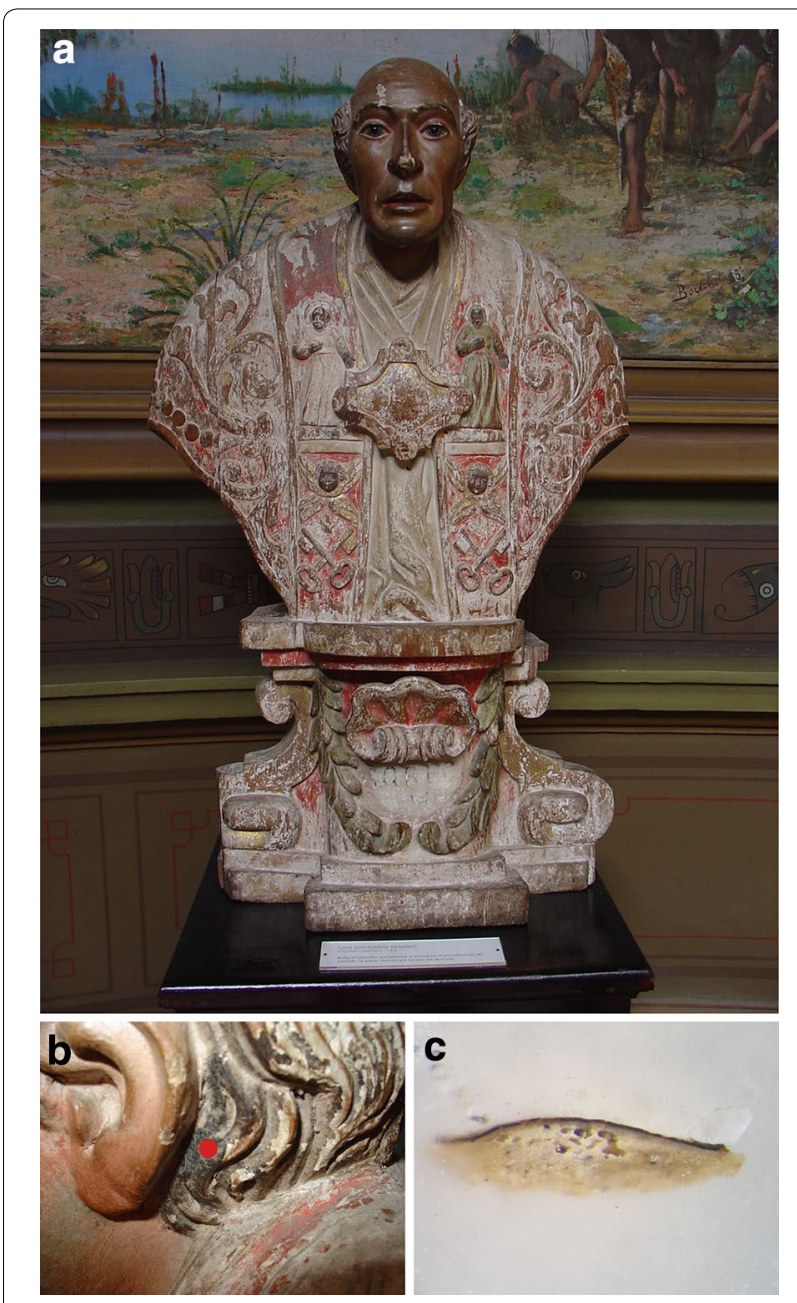

Figure 1 a Saint Gregorius Magnus; b sample location (SGM8) indicated by a red circle; $\mathbf{c}$ cross-section of sample SGM8.

sculptures [14]. The inventories left by the Jesuits after their expulsion in 1767 give account of many materialspigments such as Prussian blue, vermillion, minium, carmine, verdigris, among others - that were used by them. Recently, we have identified the pigments minium, vermilion, red earth, madder lake, copper resinate and green earth, together with calcite and gypsum as plasters, in three of the sculptures studied $[15,16]$.

In this paper microsamples from black areas of the Jesuit sculptures were analyzed by Raman microscopy, together with scanning electron microscopy with energy dispersive X-ray microanalysis (SEM-EDS) and Fourier transform infrared spectroscopy (FT-IR) as complementary techniques. The results show the potential of Raman microscopy to discriminate the carbon-based pigments of different sources used in the polychromy of the sculptures and contribute with new information on colonial art materials. 

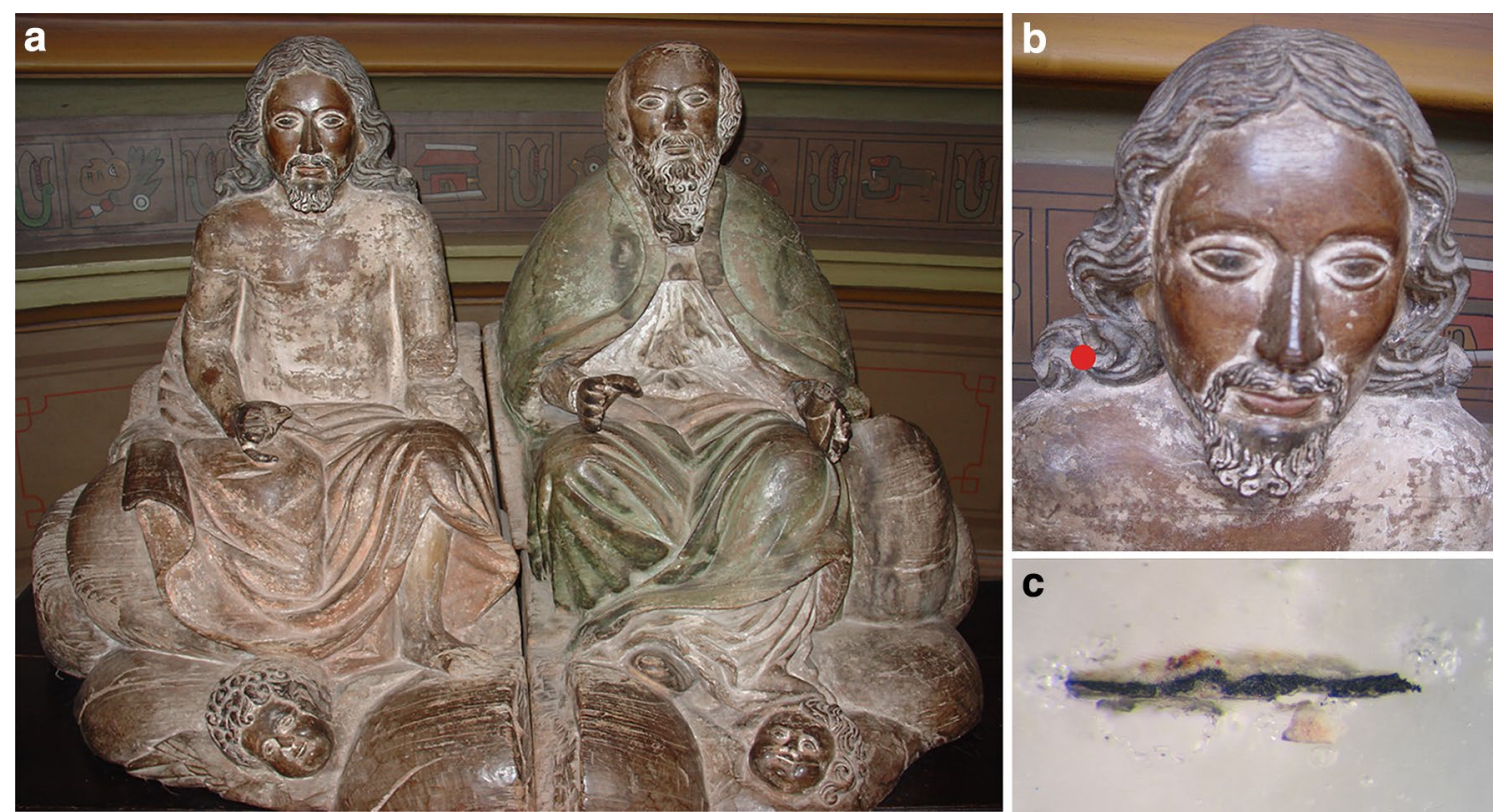

Figure $\mathbf{2}$ a The Trinity; b sample location (TRI8) indicated by a red circle; c cross-section of sample TRI8.

\section{Methods}

Four microsamples were extracted from black areas of the wooden sculptures of Saint Gregorius Magnus (Figure 1), The Trinity (Figure 2), Saint Lion the Pope (Figure 3) and Saint Benedict the Black (Figure 4). The samples were labeled SGM8, TRI8, SLP6 and SBN1, respectively (Table 1). A small quantity of each sample was mounted in an acrylic transparent resin (Subiton, Laboratories S.A., Argentina). Thin and polished cross sections were prepared from the samples according to traditional techniques of our laboratory. Carbon-based reference pigments were supplied by Zecchi, Belle arte e restauro [graphite (GRZ), lampblack (LBZ), bistre (BSZ), bitumen (BTZ), ivory black (IBZ), and Earth of Kassel (EKZ)] and Van Dyck (VDK) by Kremer Pigmente. A sample of commercial algarrobo (Prosopis sp.) charcoal (CWC) was also included.

Elemental chemical analyses of the layers of the cross section of each sample were obtained by using a Philips XL 30 ESEM scanning electron microscope. The samples were coated by sputtering with a thin (less than $80 \stackrel{2}{\AA}$ ) layer of gold. Several measurements were performed on selected areas or certain grains of each layer of the sample.

Infrared spectra of painting samples were obtained on a Nicolet Magna 550 Fourier transform spectrometer. For each sample 32 scans were recorded in the 4,000$400 \mathrm{~cm}^{-1}$ spectral range in the transmittance mode with a resolution of $4 \mathrm{~cm}^{-1}$. Spectral data were collected with OMNIC 7.3 (Thermo Electron Corp.) software. The KBr pressed disk technique ( $1 \%$ sample in $\mathrm{KBr}$ ) was used.
Raman spectra were recorded on a LabRAM HR Raman system (Horiba Jobin Yvon), equipped with two monochromator gratings and a charge coupled device detector (CCD). An 1,800 $\mathrm{g} \mathrm{mm}^{-1}$ grating and $100 \mu \mathrm{m}$ hole resulted in a $1.5 \mathrm{~cm}^{-1}$ spectral resolution. The spectrograph was coupled to an imaging microscope with $10 \times, 50 \times$ and $100 \times$ magnifications. The Ar laser line at $514.5 \mathrm{~nm}$ was used as excitation source and it was filtered to give a laser fluence or density power at the exit of the objective lens varying from 10 to $200 \mathrm{~W} \mathrm{~mm}^{-2}$. Several measurements were performed, adjusting the laser fluence to $50 \mathrm{~W} \mathrm{~mm}{ }^{-2}$, in order to ensure that the heating produced by the laser was minimized and the sample was not altered. Typically, for a $50 \times$ magnification, the spot size diameter was of about $5 \mu \mathrm{m}$. To register the Raman spectra of the polychrome sculpture samples, at least ten different points in each sample were randomly taken under the same conditions. Each spectrum was averaged over four scans with a collection time between 30 and $120 \mathrm{~s}$ for each scan, depending on the signal intensity. Raman spectra of the reference pigments were registered under the same conditions as for the sculpture samples, collecting spectra from ten different points in each sample.

\section{Results and discussion}

Black layers of samples SGM8, TRI8, SLP6 and SBN1 showed Raman spectra with D and G broad bands (Figure 5), characteristic of amorphous carbon. On the other hand, spectra from SGM8 sample also revealed the presence of iron-manganese oxide compounds. 

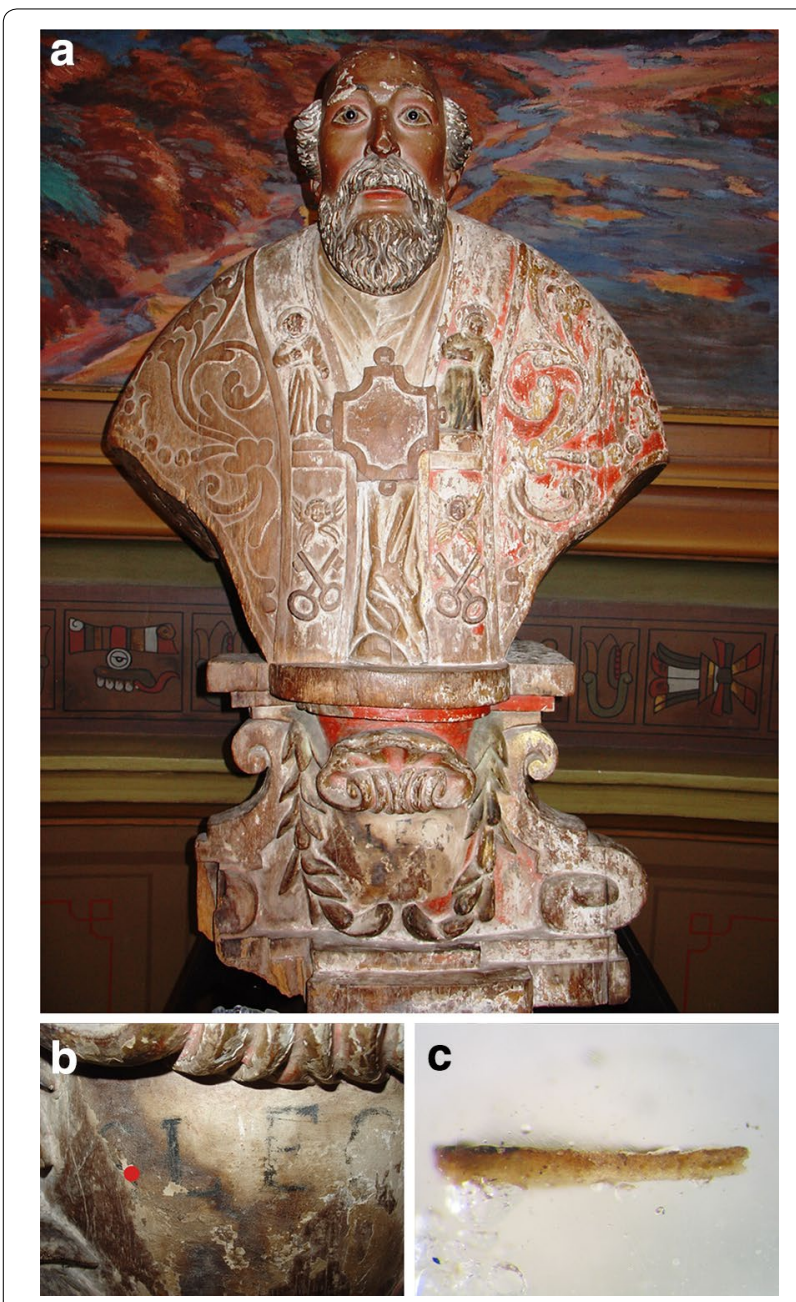

Figure 3 a Saint Lion the Pope; b sample location (SLP6) indicated by a red circle; $\mathbf{c}$ cross-section of sample SLP6.

Position, width, and relative intensity of D and G bands were analyzed for each sample and compared to that of seven references, previously studied by microRaman spectroscopy [12]. Quantitative parameters from the Raman spectra of the samples were obtained by conventional fitting procedures based on Lorentzian and Gaussian profiles [17]. The baseline was fitted using a straight line in the $1,000-1,900 \mathrm{~cm}^{-1}$ range, in order to minimize the number of parameters involved. Table 2 shows the averaged parameters over ten spectra for each sample (references and sculpture samples); errors were calculated taking into account the fitting errors and the statistical deviation over ten measurements.

In Figure 6, references and sculpture samples were arranged according to the increasing value of $\mathrm{I}_{\mathrm{D}} / \mathrm{I}_{\mathrm{G}}$ ratio, suggesting different sources for the carbon-based
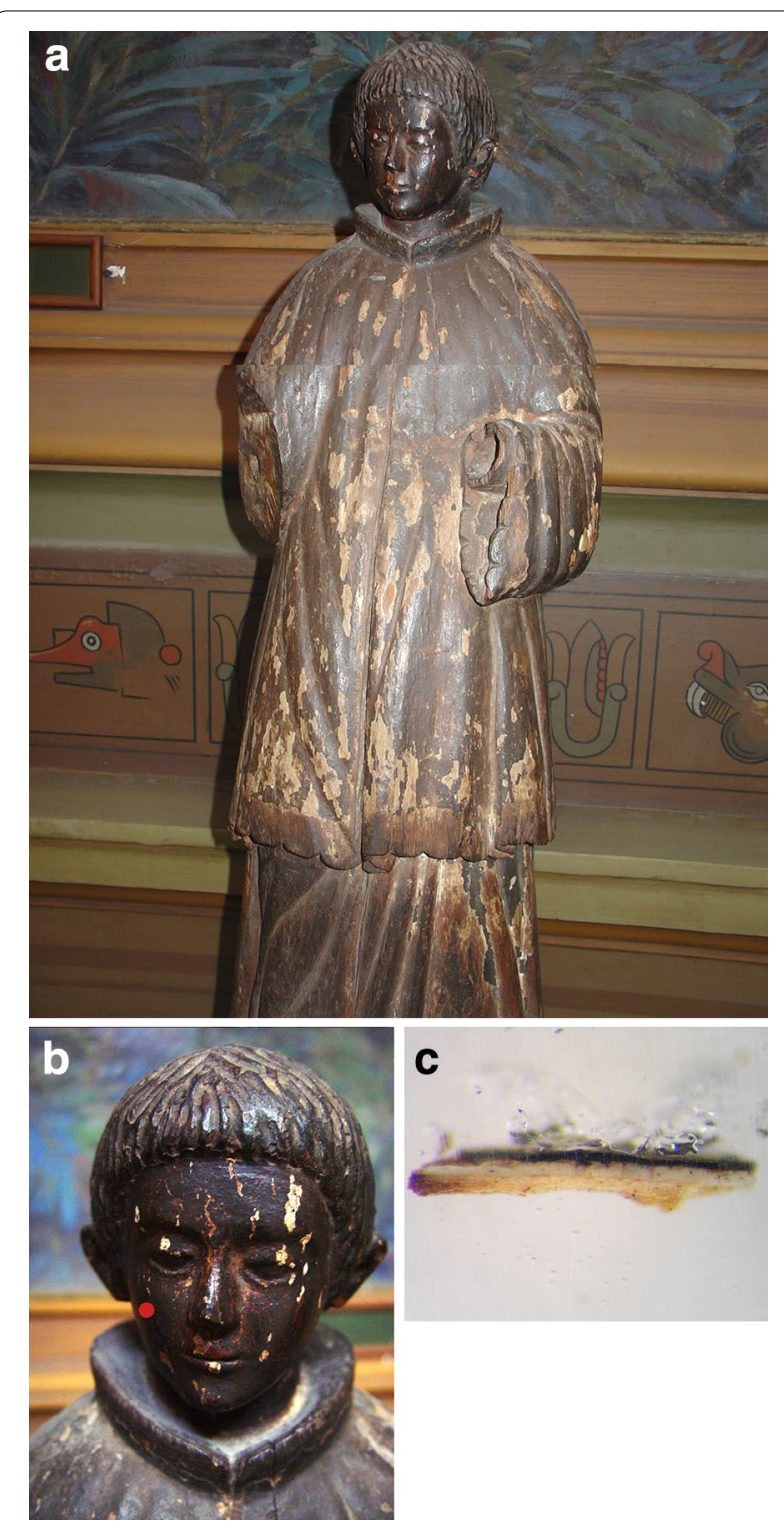

Figure 4 a Saint Benedict the Black; $\mathbf{b}$ sample location (SBN1) indicated by a red circle; $\mathbf{c}$ cross-section of sample SBN1.

pigments in samples SGM8, TRI8, SLP6, and SBN1 (0.67, $0.75,0.95$, and 0.82 , respectively).

Sample SGM8 showed D and G band positions (1,378 and $1,587 \mathrm{~cm}^{-1}$, respectively) and $\mathrm{I}_{\mathrm{D}} / \mathrm{I}_{\mathrm{G}}$ ratio $(0.67)$ very similar to those for dark earth references VDK and EKZ (Table 2), except for the full width at half maximum (FWHM) of band D $\left(\omega_{\mathrm{D}}\right)$, which showed a larger value $\left(455 \mathrm{~cm}^{-1}\right)$ than VDK and EKZ (237 and $228 \mathrm{~cm}^{-1}$, respectively). In addition to this, a broad band around $600-645 \mathrm{~cm}^{-1}$ indicated the presence of iron-manganese oxides, which is in good agreement with previous analysis of the black layer by SEM-EDS (Table 1) [16]. The 
Table 1 Description of the samples, their locations and chemical composition of pigment and plaster layers obtained by SEM-EDS

\begin{tabular}{|c|c|c|c|c|}
\hline Sample & Color & Location & Pigment layer & Plaster layer \\
\hline SGM8 & Dark brown & Hair behind the right ear & $\begin{array}{l}\text { Fe (45\%), Si (35\%), Al (8\%), Mn (8\%), Ca (2\%), } \\
\quad \text { K (2\%) }\end{array}$ & Ca (45\%), Si (41\%), S (41\%), Al (1\%) \\
\hline TRl8 & Black & Christ's hair & $\begin{array}{l}\mathrm{Ca}(42 \%), \operatorname{Si}(26 \%), \mathrm{S}(15 \%), \mathrm{Al}(8 \%), \mathrm{K}(2 \%), \\
\quad \mathrm{Fe}(2 \%), \operatorname{Mg}(2 \%), \mathrm{Cl}(<1 \%)\end{array}$ & $\begin{array}{l}\text { Ca (77\%), S (7\%), Mg (7\%), Si (6\%), Al (1\%), } \\
\text { K (1\%), Fe (<1\%), Cl (<1\%) }\end{array}$ \\
\hline SLP6 & Black & Letter $\mathrm{S}$ in the inscription & $\begin{array}{l}\text { Ca (45\%), S (39\%), Si (10\%), Al (2\%), K (2\%), } \\
\text { Fe (1\%), Cu (1\%) }\end{array}$ & $\begin{array}{l}\mathrm{Ca}(50 \%), \mathrm{S}(41 \%), \mathrm{Si}(4 \%), \mathrm{Cu}(2 \%), \mathrm{Al}(1 \%), \\
\quad \mathrm{Fe}(<1 \%), \mathrm{Mg}(<1 \%)\end{array}$ \\
\hline SBN1 & Black & Carnation (right cheek) & $\begin{array}{l}\text { Black: Ca (8\%), Si (6\%), K (6\%), Al (3\%), } \\
\quad \text { Fe (3\%), Pb (74\%) } \\
\text { White: } \mathrm{Pb}(100 \%)\end{array}$ & $\mathrm{Ca}(48 \%), \mathrm{S}(40 \%), \mathrm{Pb}(10 \%), \mathrm{Al}(<1 \%)$ \\
\hline
\end{tabular}

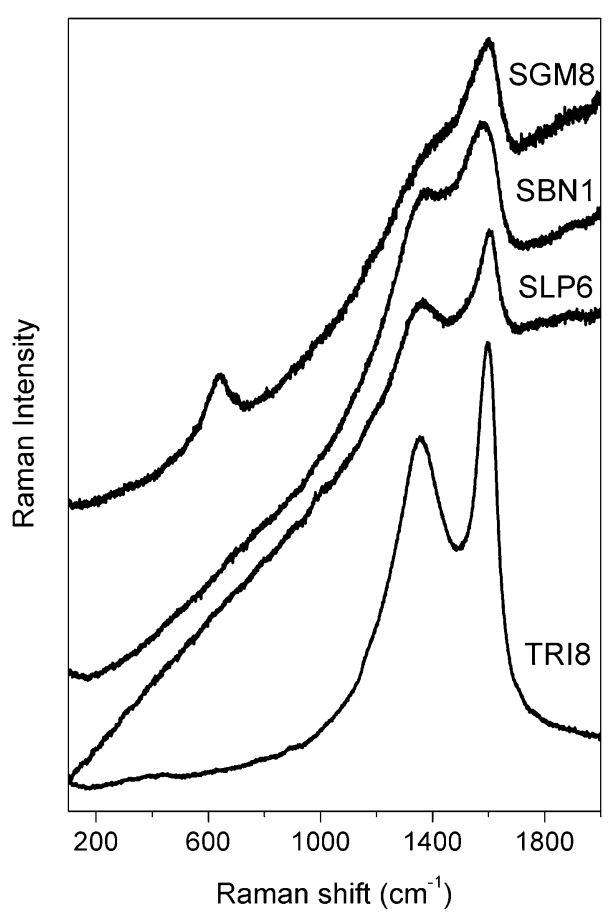

Figure 5 Raman spectra of carbon-based pigments in samples, SGM8, SBN1, SLP6, and TRI8.

presence of these oxides could produce a broadening of the D band, affecting the fitting procedure [18]. The Raman spectral parameters of sample SGM8 suggests the use of a carbon-based pigment such as Vandyke or Cassel earth, which contain humic substances together with a mineral fraction composed by clays and oxides [8]. The Raman spectrum of the plaster layer showed characteristic peaks for gypsum $\left(\mathrm{CaSO}_{4} \cdot 2 \mathrm{H}_{2} \mathrm{O}\right)$ and anhydrite $\left(\mathrm{CaSO}_{4}\right)$ at 1,009 and $1,018 \mathrm{~cm}^{-1}$, respectively (Figure 7) [19]. The IR spectrum of sample SGM8 (Figure 8) was dominated by characteristic bands of gypsum $\left(\mathrm{CaSO}_{4}\right)$ at $3,554,3,406,1,689,1,628,1,130,673$, and 600 [19] of the plaster layer, together with weaker bands at 3,900-3,000,
1,740-1,600 and 1,470-1,250 $\mathrm{cm}^{-1}$, which could be attributed to humic substances from an earth carbonbased pigment [13].

Sample TRI8 showed D and G band positions (1,357 and $1,593 \mathrm{~cm}^{-1}$, respectively) and $\mathrm{I}_{\mathrm{D}} / \mathrm{I}_{\mathrm{G}}$ ratio $(0.75) \mathrm{simi-}$ lar to charcoal (CWC) and graphite (GRZ) references (Table 2). Regarding the band width of the $\mathrm{G}$ band, samples TRI8, CWC, and GRZ showed the lowest values of $\omega_{\mathrm{D}}\left(84,75\right.$ and $67 \mathrm{~cm}^{-1}$, respectively), indicating the highest degree of graphitization among the references and sculpture samples. SEM-EDS analysis of the black layer in TRI8 revealed the presence of silicon, calcium and sulfur, together with minor amounts of aluminium, potassium, iron, chloride, and magnesium (Table 1). Minor elements as potassium and chloride could derive from plant material suggesting the use of wood charcoal as the black pigment [13]. The FTIR spectrum of sample TRI8 (Figure 8) showed typical vibrations of calcium carbonate at 1,432 and $875 \mathrm{~cm}^{-1}$ together with bands at $1,114,673$ and $599 \mathrm{~cm}^{-1}$ attributable to gypsum [20] in accordance with the presence of calcium as the major element and sulfur by SEM-EDS analysis of the plaster layer of TRI8 (Table 1). The bands at 2,921 and 2,852 $\mathrm{cm}^{-1}$ are characteristic of lipids while the band at $1,632 \mathrm{~cm}^{-1}$ together with the broad band centered at $3,405 \mathrm{~cm}^{-1}$ indicated protein. Lipid and protein staining tests on the cross-section of sample TRI8 with Sudan black (lipid) and Acid Fuchsin S (protein) confirmed the presence of a mixture of lipids and protein in the ground layer [21].

Sample SLP6 shows the highest $\mathrm{I}_{\mathrm{D}} / \mathrm{I}_{\mathrm{G}}$ ratio $(0.95)$, which is very similar to references IBZ (0.94) and LBZ (0.91). On the ground layer, the Raman spectrum showed peaks at 1,007 and $1,014 \mathrm{~cm}^{-1}$ characteristic of a mixture of gypsum and anhydrite (Figure 7). SEM-EDS analysis of the black layer revealed the presence of calcium, sulfur and silicon, together with minor elements as aluminium, potassium, iron and copper (Table 1). The absence of phosphorous discarded the presence of a bone black pigment. The FTIR spectrum (Figure 8) of SLP6 was 
Table 2 Raman spectral parameters: positions $\left(x_{D}\right.$ and $\left.x_{G}\right)$, full width at half maximum $\left(\omega_{D}\right.$ and $\left.\omega_{G}\right)$ and intensity ratio $\left(I_{D} / I_{G}\right)$ of $D$ and $G$ bands

\begin{tabular}{|c|c|c|c|c|c|c|}
\hline & & $x_{D}\left(\mathrm{~cm}^{-1}\right)$ & $\omega_{D}\left(\mathbf{c m}^{-1}\right)$ & $x_{G}\left(\mathrm{~cm}^{-1}\right)$ & $\omega_{G}\left(\mathbf{c m}^{-1}\right)$ & $\mathrm{I}_{\mathrm{D}} / \mathrm{I}_{\mathrm{G}}$ \\
\hline \multicolumn{7}{|l|}{ References } \\
\hline Graphite & GRZ & $1,351 \pm 3$ & $188 \pm 18$ & $1,598 \pm 1$ & $67 \pm 2$ & $0.78 \pm 0.13$ \\
\hline Lampblack & LBZ & $1,357 \pm 2$ & $215 \pm 7$ & $1,585 \pm 2$ & $104 \pm 4$ & $0.91 \pm 0.06$ \\
\hline Bistre & BSZ & $1,360 \pm 3$ & $334 \pm 13$ & $1,578 \pm 4$ & $116 \pm 5$ & $0.85 \pm 0.09$ \\
\hline Bitumen & BTZ & $1,394 \pm 3$ & $299 \pm 11$ & $1,603 \pm 2$ & $102 \pm 3$ & $0.79 \pm 0.06$ \\
\hline Ivory black & $\mathrm{IBZ}$ & $1,358 \pm 2$ & $274 \pm 5$ & $1,593 \pm 2$ & $102 \pm 4$ & $0.94 \pm 0.09$ \\
\hline Commercial charcoal & CWC & $1,345 \pm 2$ & $258 \pm 4$ & $1,594 \pm 1$ & $75 \pm 3$ & $0.74 \pm 0.08$ \\
\hline Van Dyck & VDK & $1,381 \pm 4$ & $237 \pm 10$ & $1,593 \pm 3$ & $106 \pm 6$ & $0.70 \pm 0.13$ \\
\hline Earth of Kassel & EKZ & $1,382 \pm 3$ & $228 \pm 7$ & $1,592 \pm 2$ & $98 \pm 3$ & $0.63 \pm 0.10$ \\
\hline \multicolumn{7}{|l|}{ Samples } \\
\hline Saint Gregorius Magnus & SGM8 & $1,378 \pm 6$ & $455 \pm 20$ & $1,587 \pm 2$ & $117 \pm 4$ & $0.67 \pm 0.09$ \\
\hline The Trinity & TRI8 & $1,357 \pm 3$ & $271 \pm 9$ & $1,593 \pm 2$ & $84 \pm 3$ & $0.75 \pm 0.10$ \\
\hline Saint Lion the Pope & SLP6 & $1,365 \pm 4$ & $412 \pm 28$ & $1,602 \pm 2$ & $134 \pm 10$ & $0.95 \pm 0.12$ \\
\hline Saint Benedict the Black & SBN1 & $1,374 \pm 3$ & $226 \pm 9$ & $1,580 \pm 3$ & $118 \pm 4$ & $0.82 \pm 0.15$ \\
\hline
\end{tabular}

Data for reference pigments were published in [12].

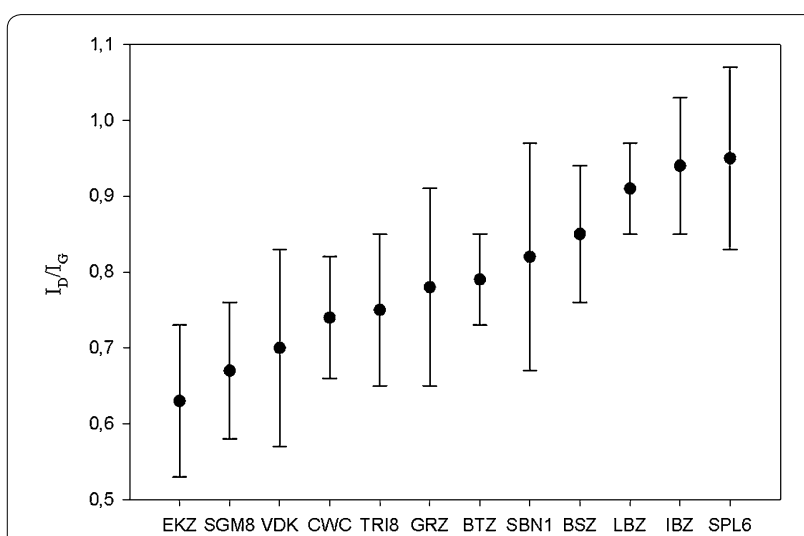

Figure $6 \mathrm{I}_{\mathrm{D}} / \mathrm{I}_{\mathrm{G}}$ ratio for references (EKZ, VDK, CWC, GRZ, BTZ, BSZ, LBZ, IBZ) and sculpture samples (SGM8, TRI8, SBN1, SLP6).

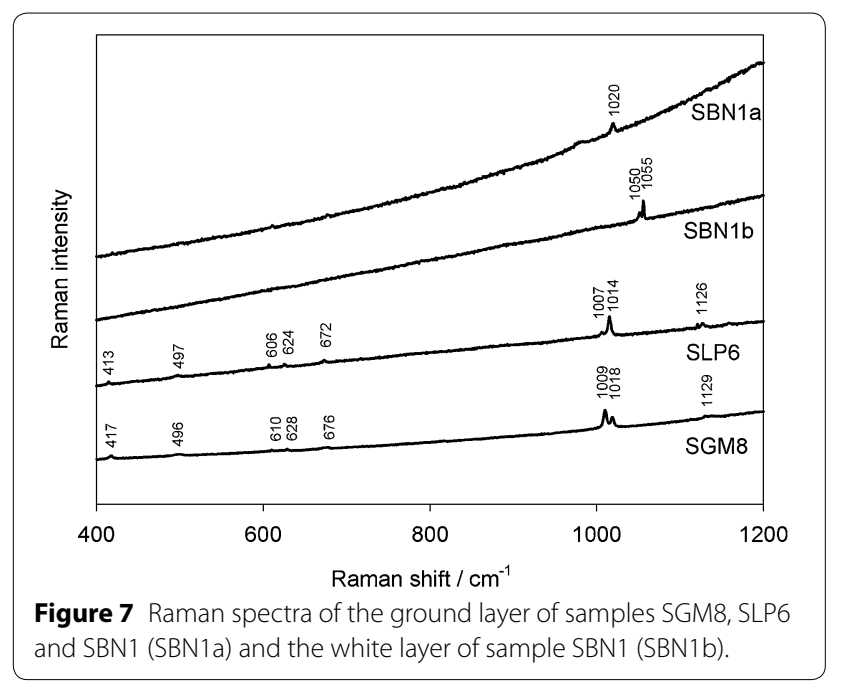

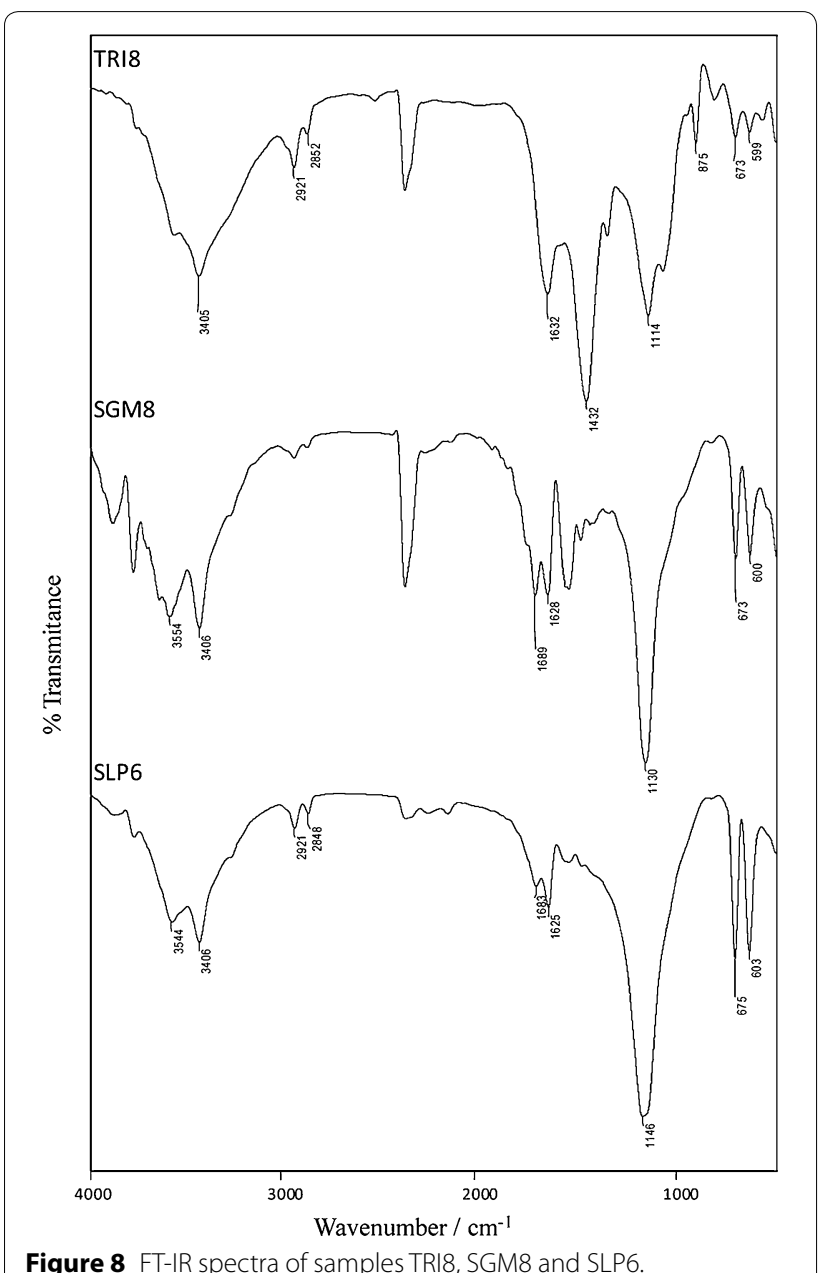

Figure 8 FT-IR spectra of samples TRI8, SGM8 and SLP6. 
dominated by gypsum bands at 3,544, 3,406, 1,683, 1,625, $1,146,675$ and $603 \mathrm{~cm}^{-1}$ from the ground layer, together with bands at 2,921 and $2,848 \mathrm{~cm}^{-1}$, characteristic of lipids. No bands due to calcium carbonate characteristic of carbonated hydroxyapatite were observed [13]. These results suggest the use of lampblack, which is soot obtained from burning oil [1].

The Raman spectrum of the black layer of SBN1 showed D and G band positions $\left(1,374\right.$ and $1,580 \mathrm{~cm}^{-1}$, respectively) and $I_{D} / I_{G}$ ratio $(0.82)$ similar to those of bistre (BSZ) (Table 2), a carbon-based pigment prepared from wood soot [13]. SEM-EDS analysis of the black layer showed the presence of lead together with minor amounts of calcium, silicon, potassium, aluminium, and iron (Table 1). The presence of potassium is typical for the carbonization of wood. The black pigment was applied over a white layer of basic lead carbonate $\left[\mathrm{PbCO}_{3} \cdot \mathrm{Pb}(\mathrm{OH})_{2}\right]$ known as lead white [22], as determined by the presence of lead in the SEM-EDS spectrum of this layer (Table 1) and a strong peak at $1,055 \mathrm{~cm}^{-1}$ together with a weak one at $1,050 \mathrm{~cm}^{-1}$ in the Raman spectrum of the white layer [19] (Figure 7). The characteristic peak of anhydrite around $1,020 \mathrm{~cm}^{-1}$ was observed in the Raman spectrum (Figure 7) of the ground layer, which is suggested to be composed of a mixture of calcium sulfate and lead white due to the presence of calcium and sulfur together with minor amounts of lead in the SEM-EDS analysis. The FTIR of SBN1 was not recorded due to the low amount of sample available.

\section{Conclusions}

In this study, carbon-based black pigments were identified by Raman microscopy in four Jesuit wooden sculptures produced in the 18th century. The images show a poor conservation condition in their polychrome layers as well as in their wood support, due to old transfers and to light and humidity exposure through time. Nevertheless, the fact that they have never been repainted-as usually happens with this kind of religious images-enabled us to develop scientific research on their original painting. The combined analysis of Raman spectral parameters (width, position and intensity of $G$ and D bands) of the painting samples and reference pigments determined by curve fitting was successfully applied to the identification of bistre, wood charcoal, lampblack, and a humic earth pigment in the Jesuit sculptures. Wood charcoal and bone black had previously been characterized by this methodology in two colonial paintings dated from the early 18th century [12]. The chemical information obtained on the black pigments used in the manufacture of the polychrome sculptures contributed to increase our knowledge on the available resources at the Jesuit Mission of Trinidad and expands our knowledge on Colonial art. At the same time, this kind of studies deeply helps in future preventive conservation and restoration labors.

\section{Authors' contributions}

MSM and EPT coordinated the study and prepared the draft manuscript. BG recorded the FT-IR spectra and prepared the cross-sections of the samples. EH, ED and MR performed the Raman microscopy analyses. EPT, EH, MR and MSM carried out the interpretation of the results. GS selected the Jesuit sculptures in the frame of our project on Colonial sculpture (PICT2011-1327) and defined the sampling. All authors have read and approved the final manuscript.

\section{Author details}

${ }^{1}$ UMYMFOR-CONICET and Departamento de Química Orgánica, Facultad de Ciencias Exactas y Naturales, Universidad de Buenos Aires, Pabellón 2, Ciudad Universitaria, C1428EGA Ciudad Autónoma de Buenos Aires, Argentina. ${ }^{2}$ Gerencia de Investigación y Aplicaciones, Comisión Nacional de Energía Atómica, Av. General Paz 1499, B1650KNA Villa Maipú, Buenos Aires, Argentina. ${ }^{3}$ Escuela de Ciencia y Tecnología, Universidad Nacional de San Martín, M. de Irigoyen 3100, B1650 San Martín, Buenos Aires, Argentina. ${ }^{4}$ Centro de Investigación en Arte, Materia y Cultura, IIAC, Universidad Nacional de Tres de Febrero, Avda. Antártida Argentina 1355, C1104ACA Ciudad Autónoma de Buenos Aires, Argentina. ${ }^{5}$ CONICET, Rivadavia 1917, C1033AAJ Buenos Aires, Argentina.

\section{Acknowledgements}

We acknowledge the Consejo Nacional de Investigaciones Científicas y Técnicas (CONICET) and the Agencia Nacional de Promoción Científica y Tecnológica (ANPCyT) for financial support. We wish to thank Fernando Marte for collecting the samples. MSM, MR, GS and EPT are Research Members of CONICET.

\section{Compliance with ethical guidelines}

\section{Competing interests}

The authors declare that they have no competing interests.

Received: 8 December 2014 Accepted: 28 May 2015

Published online: 16 June 2015

\section{References}

1. Winter J, FitzHugh EW (2007) Pigments based on carbon. In: Berrie BH (ed) Artists' pigments, vol 4. Archetype, London, p 1

2. Winter J (1993) The characterization of pigments based on carbon. Stud Conserv 28:49-66

3. Bothe C (2007) Asphalt. In: Berrie BH (ed) Artists' pigments, vol 4. University Archetype, London, p 111

4. Feller RL, Johnston-Feller RM (1997) Vandyke brown. In: FitzHugh EW (ed) Artists' pigments, vol 3. Oxford University Press, New York, p 157

5. Cavalheri AS, Balan AMOA, Künzli R, Constantino CJL (2010) Vibrational spectroscopy applied to the study of archaeological ceramic artifacts from Guarani culture in Brazil. Vib Spectrosc 54:164-168

6. Menu M (2009) L'analyze de l'art préhistorique. L'Anthropologie 113:547-558

7. Hein O, Karatasios I, Mourelatos D (2009) Byzantine wall paintings from Mani (Greece): microanalytical investigation of pigments and plasters. Anal Bioanal Chem 395:2061-2071

8. Eastaugh N, Walsh V, Chaplin T, Siddall R (2009) Pigment compendium, a dictionary and optical microscopy of historical pigments. Elsevier, Burlington

9. Escribano R, Sloan JJ, Siddique N, Sze N, Dudev T (2001) Raman spectroscopy of carbon-containing particles. Vib Spectrosc 26:179-186

10. Jehlicka J, Urban O, Pokorný J (2003) Raman spectroscopy of carbon and solid bitumens in sedimentary and metamorphic rocks. Spectrochim Acta A 59:2341-2352

11. Potgieter-Vermaak S, Maledi N, Wagner N, Van Heerden JHP, Van Grieken R, Potgieter JH (2011) Raman spectroscopy for the analysis of coal: a review. J Raman Spectrosc 42:123-129 
12. Tomasini EP, Halac EB, Reinoso M, Di Liscia EJ, Maier MS (2012) MicroRaman spectroscopy of carbon-based black pigments. J Raman Spectrosc 43:1671-1675

13. Tomasini E, Siracusano G, Maier MS (2012) Spectroscopic, morphological and chemical characterization of historic pigments based on carbon. Paths for the identification of an artistic pigment. Microchem J 102:28-37

14. Siracusano G (2011) Pigments and powers in the Andes: from the material to the symbolic in Andean cultural practices 1500-1800. Archetype Publications, London

15. Fazio AT, Papinutti L, Gómez A, Parera SD, Rodríguez Romero A, Siracusano G et al (2010) Fungal deterioration of a Jesuit South American polychrome wood sculpture. Int Biodeterior Biodegrad 64:694-701

16. Gómez BA, Parera SD, Siracusano G, Maier MS (2010) Integrated analytical techniques for the characterization of painting materials in two South American polychrome sculptures. e-Preserv Sci 7:1-7

17. Beyssac O, Goffé B, Petitet JP, Froigneux E, Moreau M, Rouzaud JN (2003) On the characterization of disordered and heterogeneous carbonaceous materials by Raman spectroscopy. Spectrochim Acta A 59:2267-2276
18. Hernanz A, Gavira-Vallejo JM, Ruiz-López JF (2006) Introduction to Raman microscopy of prehistoric rock paintings from the Sierra de las Cuerdas, Cuenca, Spain. J Raman Spectrosc 37:1054-1062

19. Burgio L, Clark RJH (2001) Library of FT-Raman spectra of pigments, minerals, pigment media and varnishes, and supplement to existing library of Raman spectra of pigments with visible excitation. Spectrochim Acta Part A 57:1491-1521

20. Derrick MR, Stulik D, Landry JM (1999) Infrared spectroscopy in conservation science. The Getty Conservation Institute, Los Angeles

21. Masschelein-Kleiner $L$ (1986) Analysis of paint media, varnishes and adhesives. PACT 13:185-207

22. Gettens RJ, Kühn H, Chase WT (1993) Lead white. In: Roy A (ed) Artists' pigments, vol 2. Oxford University Press, Oxford, p 67

\section{Publish with ChemistryCentral and every scientist can read your work free of charge \\ "Open access provides opportunities to our colleagues in other parts of the globe, by allowing anyone to view the content free of charge."}

W. Jeffery Hurst, The Hershey Company.

- available free of charge to the entire scientific community

- peer reviewed and published immediately upon acceptance

- cited in PubMed and archived on PubMed Central

- yours - you keep the copyright

Submit your manuscript here:

http://www.chemistrycentral.com/manuscript/<smiles>c1ccccc1</smiles>

ChemistryCentral 